ANNALS OF “DUNAREA DE JOS” UNIVERSITY OF GALATI

MATHEMATICS, PHYSICS, THEORETICAL MECHANICS

FASCICLE II, YEAR XIII (XLIV) 2021, No. 1

DOI: https://doi.org/10.35219/ann-ugal-math-phys-mec.2021.1.01

\title{
STUDY OF THE BIOSORPTION EFFICIENCY OF SEAWEED SPECIES COLLECTED FROM THE BLACK SEA FOR HEAVY METALS REMOVAL IN INDUSTRIAL WASTEWATERS
}

\author{
Florina Cristiana Căpriţă ${ }^{1,2}$, Antoaneta Ene $1,2,3$ \\ I "Dunarea de Jos" University of Galati, Doctoral School of Mechanical and Industrial Engineering, 47 Domneasca \\ St., RO-800008, Galati, Romania \\ ${ }^{2}$ INPOLDE interdisciplinary research network, ReForm-UDJG Platform, Dunarea de Jos University of Galati, 111 \\ Domneasca St., 800201 Galati, Romania \\ 3 "Dunarea de Jos" University of Galati, Faculty of Sciences and Environment, Chemistry, Physics and Environment \\ Department, 111 Domneasca St., 111, 800201, Galati, Romania
}

\begin{abstract}
In this article, it will be presented the results obtained from research conducted in order to reduce the concentrations of metals in industrial wastewater resulted from heavy metal polluting industries, especially the metallurgical industry. Most of the world's water sources are profoundly negatively affected by human activities, and the population faces critical water supply and drinking water quality problems. Millions of people develop various diseases from drinking water from unsafe or poor quality sources, creating a global public health problem. Due to massive industrialisation, current water treatment methods are outdated, which is why water treatment and purification laws, regulations, and controls need to be updated to minimise and stop contamination of the food chain. It is the responsibility of the researchers to make the public aware of the dangers to which they are exposed due to their own negligence and to offer possible solutions to these problems. New, reliable, viable, cheap, and sustainable technologies must be developed to improve drinking water quality. One such technology that can be developed and implemented is using the biological method of biosorption. Stranded seaweed on the Romanian Black Sea coast is currently treated as waste, but it could be exploited as biomass in the biosorption process. The research aimed to investigate the possibility of valorification of macrophyte seaweed species in this direction. Five different species of stranded macrophyte seaweed were collected and used to remove selected metallic ions $(\mathrm{Cr}, \mathrm{Fe}, \mathrm{Zn}, \mathrm{Cu}$ ) from a source of wastewater resulted from the metallurgical industry processes. The wastewater samples were analyzed before and after the application of the biosorption technique using the spectrophotometric method.
\end{abstract}

Keywords: biosorption, heavy metals, wastewater, seaweed, Black Sea, Romania.

\section{INTRODUCTION}

From the available statistical data on the evolution of the world's population, we can see that in 1950 the world's population was 2.5 billion, today it is 7.8 billion, and predictions show that the 10 billion mark will be exceeded somewhere between the years 2050 and 2060, more precisely, in 2056 [1].

Over the next 30 years, the population will expand by a further $28.21 \%$. This aspect needs to be taken into consideration in order to rethink how we utilise the planet's natural resources. Also, for energyconsuming industries, legislation needs to be rethought so that they are made to shift towards replacing energy consumption from non-renewable sources with energy from renewable sources. 


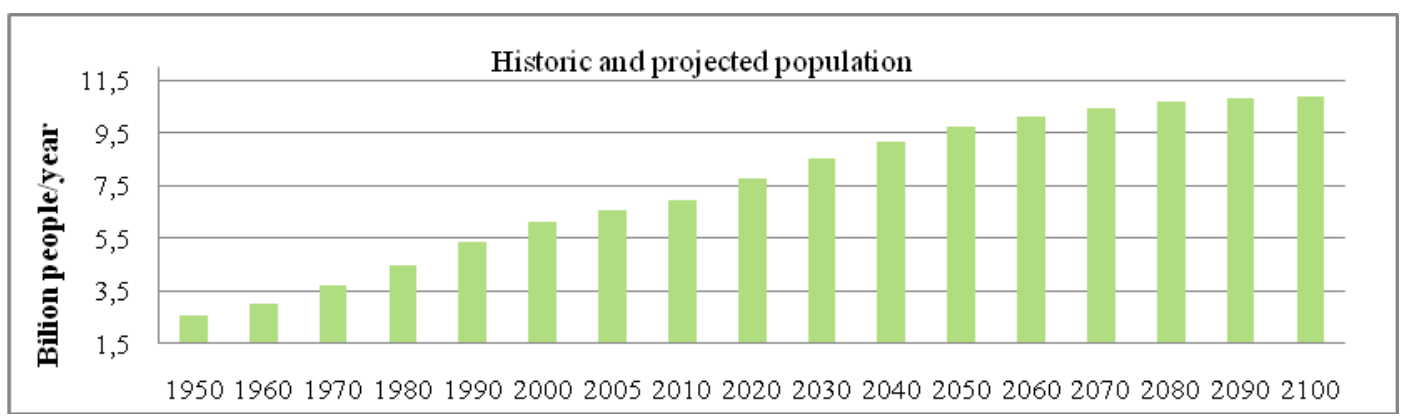

Fig. 1. The estimation of population evolution (processed after [1])

Accelerated population growth will generate various problems [2] related to the aggressive exploitation of food and water sources and the generation of waste and pollutants. Current methods of resource exploitation, in terms of the technologies used, do not comply with the principles of sustainable development, therefore it is necessary to improve current technologies or implement new ones that operate at maximum efficiency and generate as little waste and pollutants as possible. Nowadays, society is facing an irrational consumption of resources, which will lead in time to their rapid depletion and to the degradation of environmental factors. In order to prevent this from occurring, it is necessary to implement technologies that use renewable energy and alternative fuels as a source of energy and that can use certain categories of waste. In addition to the environmental benefits of waste recovery, introducing it as a raw material in various technological processes can considerably reduce production costs [3-5].

Water constitutes a vital resource for sustaining life on earth [6] and it is not a renewable resource if its quality is altered with every human action and if its self-purification capacity is exceeded. The state of water quality has a direct environmental, social, and economic impact. The availability of limited freshwater resources worldwide is increasingly scarce due to growing pollution caused by the discharge of large quantities of inadequately treated or untreated wastewaters.

Water pollutants can be classified into organic, inorganic, biological, suspended solids, radioactive, thermal, agricultural, nutrients, and other pollutants. Organic and inorganic pollutants are found in industrial and domestic wastewater effluents [7]. Of all types of pollution, heavy metal pollution is a global concern [8] because, unlike organic pollutants, heavy metals do not degrade [9], they accumulate in living organisms $[8,10]$, enter the food chain, and reach the top of the food chain, causing multiple health problems to the human population [11]. The main sources of heavy metal contaminants are the mining industry, metallurgical industry, chemical industry, thermoelectric industry, pesticide and fertilizer industry, coal burning, wastewater, and product waste disposal [12, 13].

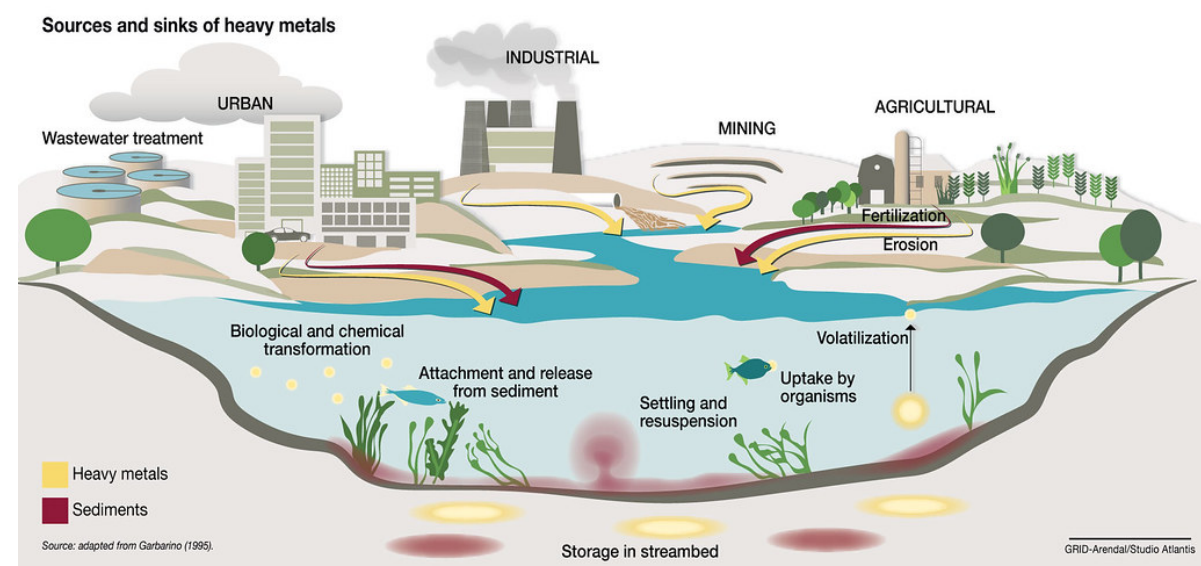

Fig. 2. Sources and sinks of heavy metals [14] 
Common methods for removing heavy metals from wastewater that are widely used are chemical precipitation, membrane separation, ion exchange, reverse osmosis, and activated carbon adsorption [13, 15]. All these methods are effective but they are selective and costly. One method that has come to be studied quite intensively nowadays is the adsorption technique, an efficient and economical method that provides the advantage of flexibility in design, functioning, recovery, and regeneration of adsorbates, the process being reversible [13].

Biosorption, on the other hand, is a much more advantageous technique in terms of the importance of environmental protection, as it is a physico-chemical process, based on a variety of mechanisms, including absorption, adsorption, ion exchange, surface complexation and precipitation [16], using living or dead microorganisms, such as vegetal materials, agricultural and industrial wastes [17], bacteria [18,19], fungi [20], yeasts [9, 21] and seaweeds [22-27]. The biosorption technique is an ecological and cost-effective alternative for wastewater treatments. Biosorption is a process by which the biomass used has the property of retaining and concentrating heavy metal pollutants from liquid effluents. Many biological materials, such as bacteria, fungi, and algae, demonstrated their biosorption capacity, but the algae have been noted to have an increased potential $[25,28]$. Today seaweeds are cultivated and exploited in the food, pharmaceutical, cosmetic, and biofuel industries [29]. Beach cast algae and wild macroalgae populations can be exploited as food and fertilizer. As regards the processing of seaweed from farming, they are subject to the legislation of the field where they will be used as raw material, but for the processing of stranded seaweed, there is no legislation or recommendations from the competent authorities, which is why, in Romania and many other countries, they are considered as simple waste [30].

There is no data on the precise estimation of the quantities of stranded seaweed on the Romanian Black Sea coast, but data provided through the media by the authorities responsible for beach management are available, and according to them, in 2021, more than 10,000 tons were collected by midAugust [31], and in 2020, 3,600 tons only in the first two weeks of August [32].

And according to statistical data provided by the National Institute of Statistics, the structure of wastewater generated in 2018 and 2019 is highlighted in Figure 3 a) and b).

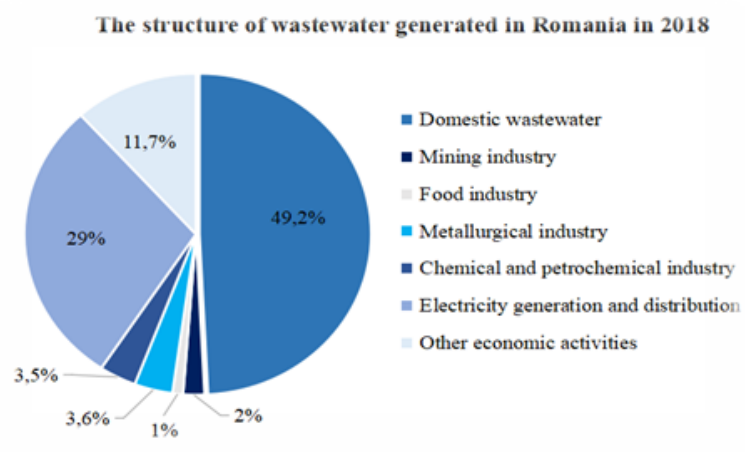

a)

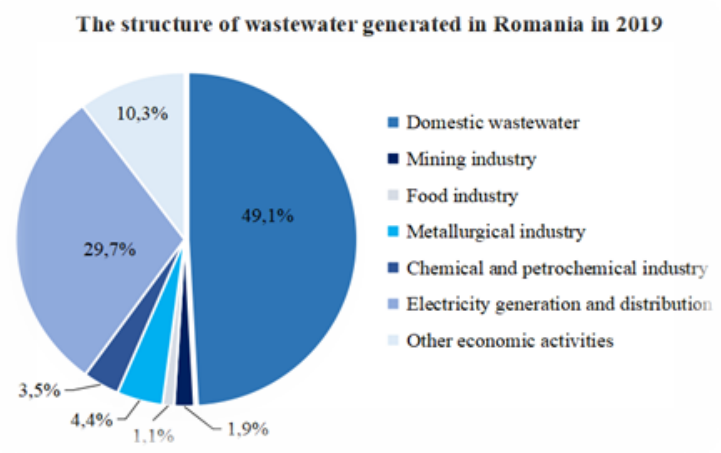

b)

Fig. 3. Structure of wastewater generated in Romania, a) in 2018 (processed after [33]) and b) in 2019 (processed after [34])

An analysis of the structure of the wastewater generated in 2019 and 2018 shows that the proportion is not very different. In 2019, compared to $2018,0.1 \%$ less domestic wastewater was generated, $0.1 \%$ less wastewater from the mining industry, $0.1 \%$ more from the food industry, $0.8 \%$ higher volume of wastewater from the metallurgical industry, the volume of wastewater generated by the chemical and petrochemical industry remained constant, wastewater generated from the production and distribution of electricity increased by $0.7 \%$, while $1.4 \%$ wastewater generated by other economic activities decreased. 
Table 1. Average annual quantities of heavy metals from wastewater generated in 2019 and 2018 in Romania [34, 33]

\begin{tabular}{lllllc}
\hline Tons/year & Copper & Chromium & Nickel & Lead & Zinc \\
\hline $\begin{array}{l}\text { Total pollutants } \\
\text { Present in industrial wastewater }\end{array}$ & 38.9 & 7.0 & 7.3 & 22.8 & 98.7 \\
$\begin{array}{l}\text { Total pollutants } \\
\begin{array}{l}\text { Present in domestic wastewater } \\
\text { Total pollutants in 2019 }\end{array}\end{array}$ & 5.3 & 1.8 & 3.5 & 4.4 & 23.2 \\
$\begin{array}{l}\text { Total pollutants } \\
\text { Present in industrial wastewater }\end{array}$ & 44.2 & 8.8 & 10.8 & 27.2 & 121.9 \\
$\begin{array}{l}\text { Total pollutants } \\
\text { Present in domestic wastewater }\end{array}$ & 22.6 & 5.4 & 5.3 & 10.4 & 70.8 \\
\begin{tabular}{l} 
Total pollutants in 2018 \\
\hline
\end{tabular} & 51.2 & 7.0 & 3.7 & 4.3 & 20.2 \\
\hline
\end{tabular}

As can be observed in Table 1, wastewater generated at the national scale in 2019 was more loaded with chromium, nickel, lead, and zinc pollutants compared to 2018 data. Only in the case of the copper contaminant, a decrease of 7 tons was observed in 2019 compared to 2018. In 2019, compared to 2018, the 5 pollutants (copper, chromium, nickel, lead, and zinc) were found in higher quantities in wastewater generated by industries. In 2018, the amount of copper in wastewater sources resulting from domestic activities was 22.6 tons per year, while in 2019, the amount of this pollutant was reduced to only 5.3 tons per year.

In terms of wastewater treatment, Romania is in a much better situation compared to countries such as Albania, Bosnia and Herzegovina, Bulgaria, Serbia, and Turkey, according to an analysis carried out in 2017, meaning that we generate a low volume of wastewater that is discharged untreated into the effluent [35] however, some improvements are needed to reach the standards required by the European Union.

Knowing all these data, the present research aims to determine the possibility of using stranded macrophytic marine algae from the Black Sea coast of Romania as biomass used in the biosorption technique to reduce heavy metal pollutants from industrial wastewater. In this way, stranded seaweed waste can be put to use in an area where it is really needed, thus contributing to sustainable development.

\section{MATERIALS AND METHODS}

In the present research regarding the possibility of valorification of stranded macrophyte marine algae by using the biosorption technique, the biomass of five different species of macrophytes were used, samples were collected from the Black Sea shore, Modern beach, Constanta area, Romania.

The 5 species collected and used were: Ulva rigida, Punctaria latifolia, Pyropia leucosticta, Callithamnion corymbosum, and Cladophora sericea. After sampling the algae were washed with potable water and distilled water to remove possible epiphytic algal debris and sand particles and dried in an oven at $105{ }^{\circ} \mathrm{C}$ with a varied time for each sample, from 2 hours and 10 minutes for Callithamnion corymbosum to 2 hours and 40 minutes for Ulva rigida. After drying, the samples were crushed and then grinded, and for determining the particle size distribution, the materials were subjected to the dry sieving process and the $500 \mu$ particle size fraction was used.

The prepared materials were used to remove $\mathrm{Zn}, \mathrm{Cr}, \mathrm{Cu}$, and $\mathrm{Fe}$ pollutants from a wastewater source originating from the metallurgical industry. Laboratory procedures were as follows: $1 \mathrm{~g}$ of material was introduced separately into $100 \mathrm{ml}$ of wastewater. The mixture was stirred at $800 \mathrm{rpm}$ using a magnetic stirrer for 30 minutes [37].

In order to show the biosorption capacity of the seaweed, the wastewater samples were analysed using the HACH DR 2800 spectrophotometer before and after the biosorption technique was applied.

The experimental data were processed in the laboratory of INPOLDE research centre, multidisciplinary platform ReForm-UDJG of "Dunarea de Jos" University of Galati, Romania. 


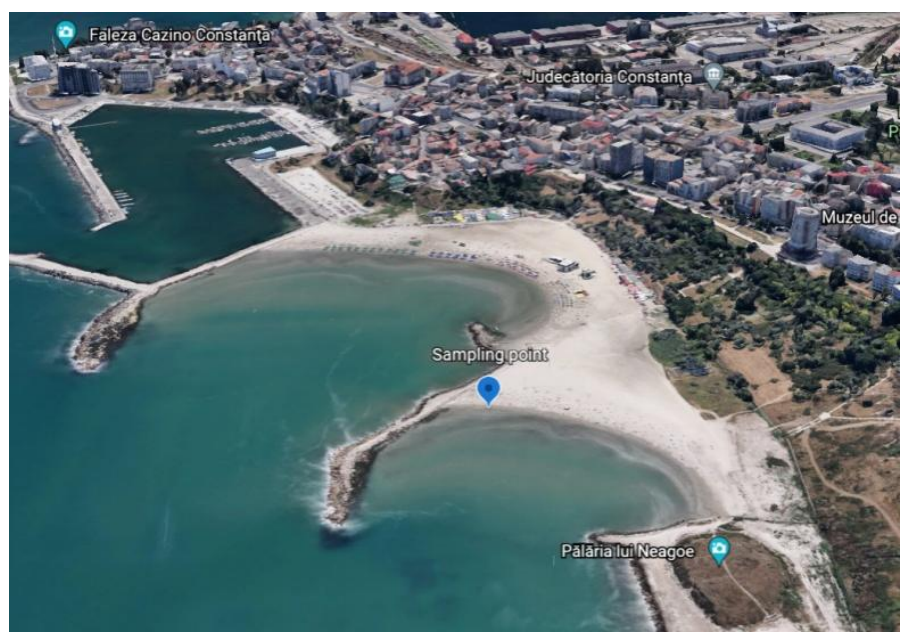

Fig. 4. Sampling point location, Romanian coast, Constanţa area, coordinates: $44^{\circ} 10^{\prime} 53^{\prime \prime} \mathrm{N}$ $28^{\circ} 39^{\prime} 25^{\prime \prime} E[36]$

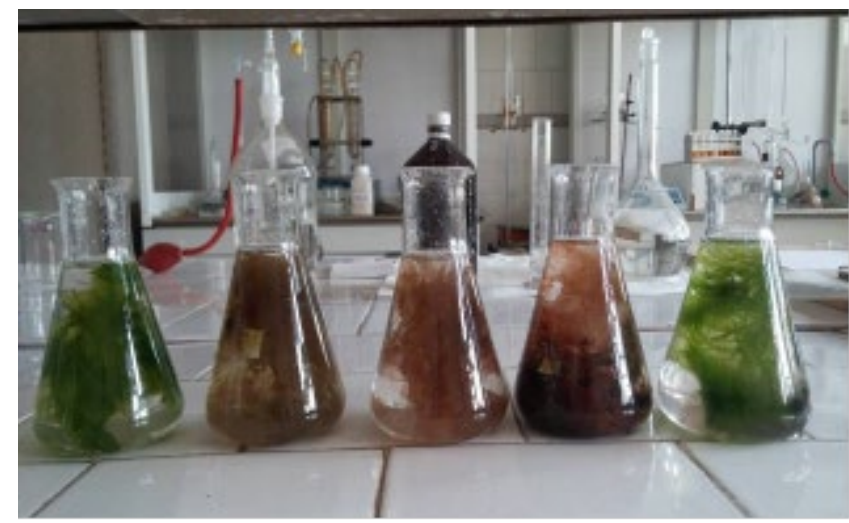

Fig. 5. The five species of algae used to remove pollutants

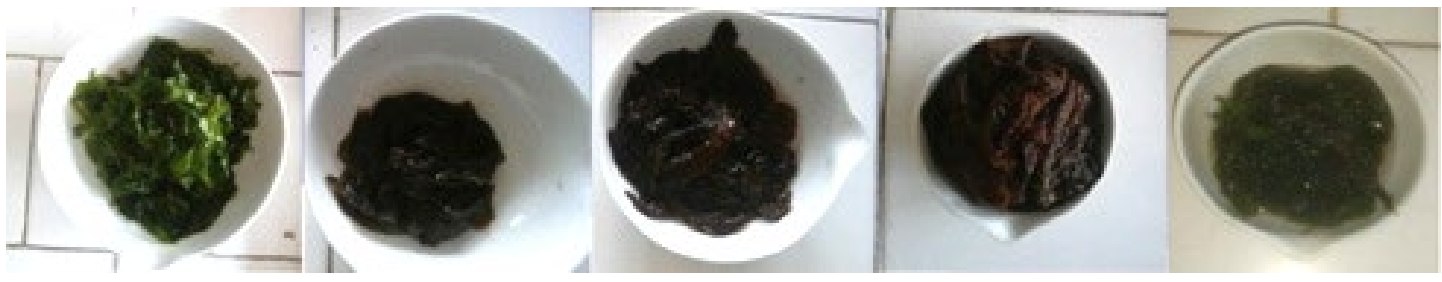

Fig. 6. Ulva rigida, Punctaria latifolia, Pyropia leucosticta, Callithamnion corymbosum, and Cladophora sericea

It should be noted that no treatments were applied to the algae with the purpose of improving their pollutant retention properties, precisely in order to observe their natural capacity, and therefore the possibility of using them as such, with a few preparation steps as possible. And for the separation of the two phases, the samples were filtered on quantitative filter paper, weighing $80 \mathrm{~g} / \mathrm{m}^{2}$, thus being able to recover the adsorbent. 


\subsection{RESULTS AND DISCUTIONS}

In accordance with the Technical Regulation NTPA-002 dated 28 February 2002 on the conditions of wastewater discharge into the sewage networks of the localities and directly into the treatment plants, the analysed wastewater shows exceedances on the maximum allowable concentrations of pollutants based on $\mathrm{Zn}, \mathrm{Cu}$, and $\mathrm{Fe}$.

Tabel 2. Biosorption technique application results using seaweed.

\begin{tabular}{|c|c|c|c|c|c|c|c|}
\hline \multicolumn{8}{|c|}{ Algae treatments } \\
\hline $\begin{array}{c}\text { Determination, } \\
\mathrm{mg} / \mathrm{l}\end{array}$ & Wastewater & $\begin{array}{c}\text { NTPA } \\
002\end{array}$ & $\begin{array}{l}\text { Ulva } \\
\text { rigida }\end{array}$ & $\begin{array}{l}\text { Punctaria } \\
\text { latifolia }\end{array}$ & $\begin{array}{l}\text { Pyropia } \\
\text { leucosticta }\end{array}$ & $\begin{array}{l}\text { Callithamnion } \\
\text { corymbosum }\end{array}$ & $\begin{array}{l}\text { Cladophora } \\
\text { sericea }\end{array}$ \\
\hline $\mathbf{Z n}^{2+}$ & 2.13 & 1.0 & 0.6 & 0.47 & 0.6 & 0.93 & 0.84 \\
\hline $\mathrm{Cr}^{3+} \& \mathrm{Cr}^{6^{+}}$ & 0.94 & 1.5 & 0.54 & 0.55 & 0.73 & 0.62 & 0.33 \\
\hline $\mathbf{C u}^{2+}$ & 4.47 & 0.2 & 1.32 & 1.15 & 3.1 & 1.21 & 1.24 \\
\hline $\mathrm{Fe}^{2+} \& \mathrm{Fe}^{3+}$ & 9.81 & 5.0 & 3.95 & 2.76 & 3.7 & 2.89 & 1.12 \\
\hline
\end{tabular}

\section{$\mathrm{Zn}^{2+}$ adsorption efficiency}

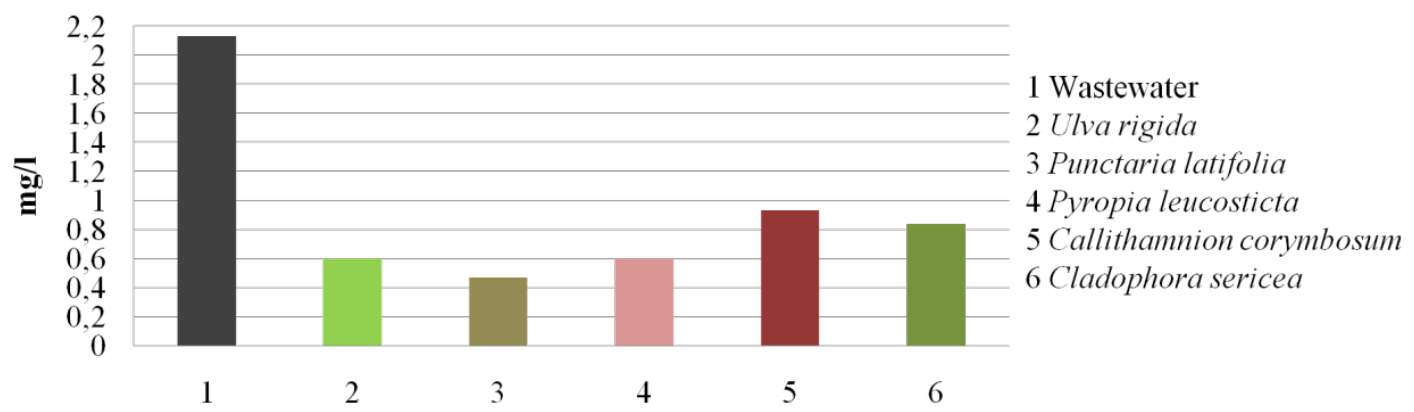

Fig. 7. Effectiveness of algae treatments in $\mathrm{Zn}^{2+}$ concentration reduction

Among the five algal species analysed, species Punctaria latifolia reduced $\mathrm{Zn}$ concentration by $77.93 \%$, with the highest efficiency, and algal species Callithamnion corymbosum had the lowest efficiency of $56.34 \%$.All five algae species were able to reduce the $\mathrm{Zn}$ concentration below the maximum allowable limit, making them suitable for this purpose. The most effective treatments were those using: Punctaria latifolia $>$ Ulva rigida $>$ Pyropia leucosticte $>$ Cladophora sericea $>$ Callithamnion corymbosum.

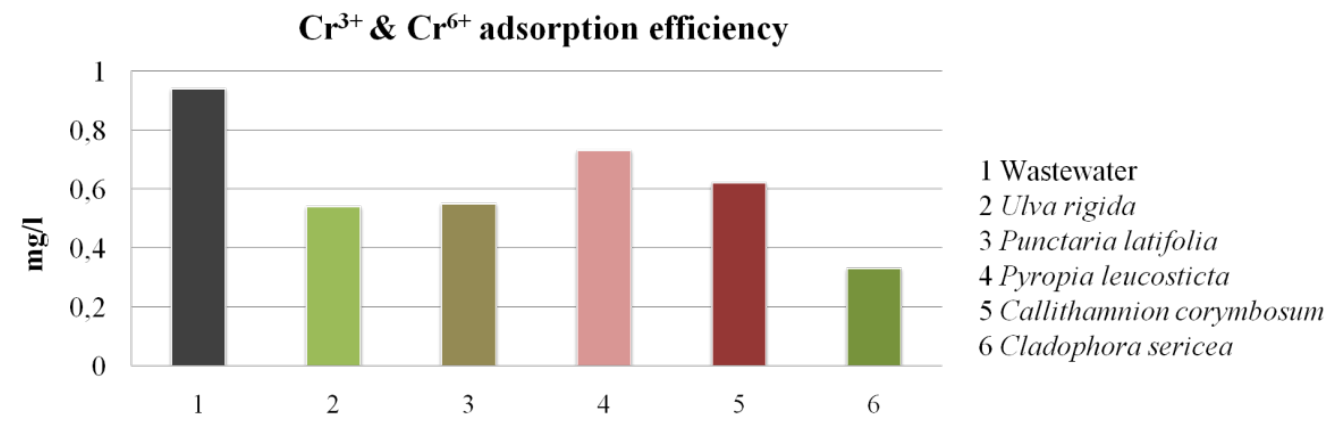

Fig. 8. Effectiveness of algae treatments in $\mathrm{Cr}^{3+} \& \mathrm{Cr}^{6+}$ concentration reduction 
The initial $\mathrm{Cr}$ concentration found in the wastewater is below the maximum allowable limit, thus not causing an environmental problem, however, seaweed could reduce this pollutant by at least $22.34 \%$ using Pyropia leucosticta algae species and at most $64.89 \%$ using species Cladophora sericea. The most effective treatments were those using:

Cladophora sericea $>$ Ulva rigida $>$ Punctaria latifolia $>$ Callithamnion corymbosum $>$ Pyropia leucosticte

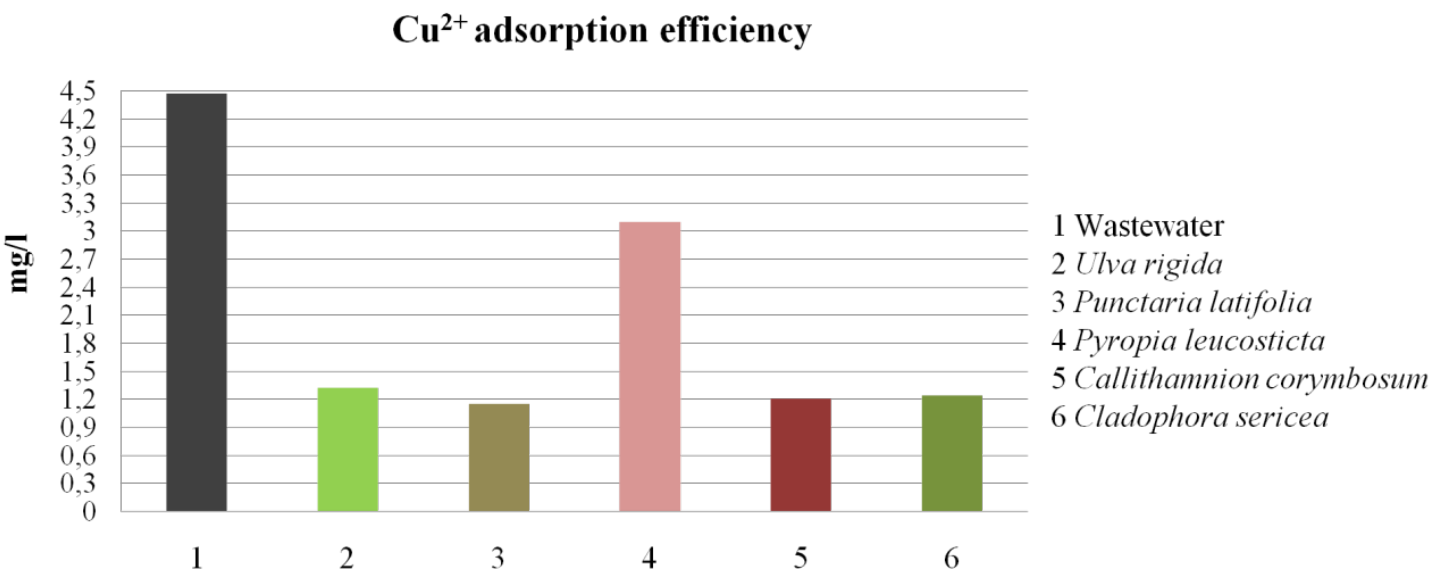

Fig. 9. Effectiveness of algae treatments in $\mathrm{Cu}^{2+}$ concentration reduction

For the $\mathrm{Cu}$-based pollutant, high exceedances have been recorded and the five algal species have failed to reduce the pollutant below the maximum limit imposed by NTPA-002 but show a fairly high biosorption efficiency. Species Punctaria latifolia was able to reduce $\mathrm{Cu}$ concentration by $74.27 \%$ and the lowest efficiency was achieved by species Pyropia leucosticta with only $30.65 \%$. The most effective treatments were those using:

Punctaria latifolia $>$ Callithamnion corymbosum $>$ Cladophora sericea $>$ Ulva rigida $>$ Pyropia leucosticta

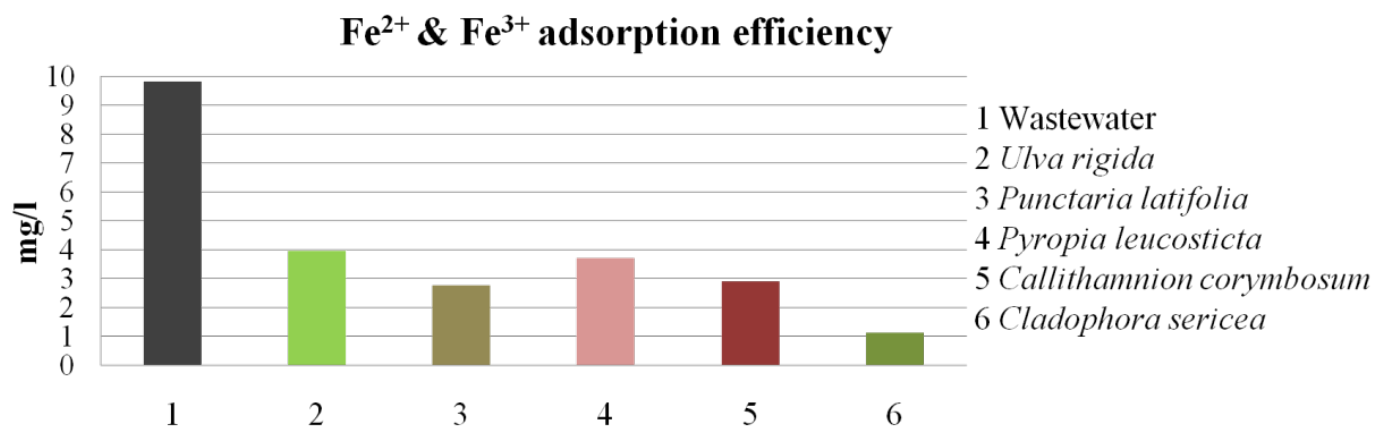

Fig. 10. Effectiveness of algae treatments in $\mathrm{Fe}^{2+} \& \mathrm{Fe}^{3+}$ concentration reduction

As a result of the determination of Fe concentration, it is observed that all five species show an affinity for $\mathrm{Fe}$, with all five managing to reduce the concentration below the maximum value required by legislation. The species Cladophora sericea shows efficiency of $88.58 \%$ in reducing this pollutant, while the lowest efficiency was recorded by the species Ulva rigida of only $59.73 \%$. The most effective treatments were those using:

Cladophora sericea $>$ Punctaria latifolia $>$ Callithamnion corymbosum $>$ Pyropia leucosticta $>$ Ulva rigida 


\section{CONCLUSIONS}

The accelerated development of industries in pursuit of profit and neglect of environmental legislation will lead to serious problems in the near future. Population growth will lead to intensive farming, draining of the planet's resources, and causing considerably more waste. Irresponsible consumption of resources and the generation of complex pollutants will reduce the capacity of pollutant removal and discharging insufficiently treated wastewater directly into the effluent will have negative effects on the aquatic environment.

Tougher environmental legislation and controls are needed to ensure progress towards the protection of the environment, natural resources, and public health. Current methods of wastewater treatment are selective and expensive and need to be improved so that they can be used in the distant future. Water quality is constantly changing and its status as an inexhaustible resource is uncertain given the decreasing degree of self-purification.

For environmental protection, it is necessary to implement new methods of reducing pollutants and newer studies in the field have focused on the use of waste for such purposes, contributing to sustainable development.

Stranded seaweed are among these wastes that can be used for this very specific goal, so they can be used to remove metals from industrial and domestic wastewater. The biosorption method has a number of advantages that make it an innovative solution. This research demonstrates that seaweed can be exploited in this direction. All five species of stranded macrophytic seaweed that have been studied, can be used to reduce $\mathrm{Zn}, \mathrm{Cr}, \mathrm{Cu}$, and Fe concentrations from wastewater. Algae of the species Punctaria latifolia show the highest yield for the removal of the four metals studied, and algae of the species Pyropia leucostica the lowest yield.

It was observed that for the $\mathrm{Zn}$ concentration removal, the five algal species could have efficiencies ranging from 56 to $78 \%$, reducing from $1.2 \mathrm{mg} / 1$ to $1.66 \mathrm{mg} / \mathrm{l}$ while for $\mathrm{Cr}$ concentration reduction, the algae had an efficiency ranging from 22 to $65 \%$, reducing a minimum of $0.2 \mathrm{mg} / 1$ to 0.61 $\mathrm{mg} / \mathrm{l}$ of $\mathrm{Cr}$. The efficiency in reducing $\mathrm{Cu}$ concentration using seaweed waste varied between 31 and $74 \%$, reducing from $1.37 \mathrm{mg} / 1$ to $3.32 \mathrm{mg} / \mathrm{l}$ of this pollutant and the capacity in reducing Fe concentration was in the range of $60-89 \%$, with the algae managing to reduce from $5.86 \mathrm{mg} / 1$ to $8.69 \mathrm{mg} / 1 \mathrm{of} \mathrm{Fe}$. Given the very short contact time between the two phases and the fact that the algae were not subjected to additional treatments to improve the adsorption capacity, it can be concluded that seaweed can be exploited for the reduction of heavy metals. The fact that the wastewater was filtered on filter paper after the contact time to remove solid particles from the algae also contributed to these positive values, as it is known that cellulose also has the ability to adsorb various ions.

Romania disposes of quite large quantities of stranded seaweed waste during the summer. These could be recovered, the costs of using this method being very low, with a positive efficiency/cost ratio.

The influent characteristics of the biosorption method can be adjusted so that their pollutant reduction efficiency is increased while incurring the lowest possible costs. Macrophytic seaweed waste stranded at the Black Sea coast could replace some adsorbents currently used, or at least be introduced as an additional treatment.

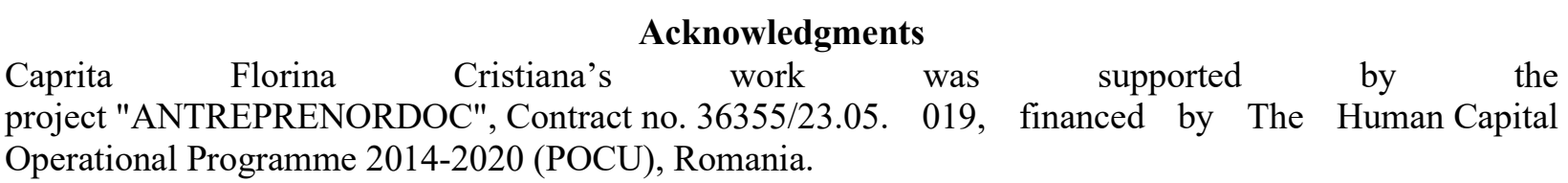

\section{REFERENCES}

[1] RoserM., RitchieH., Ortiz-Ospina E.,World Population Growth,Published online at OurWorldInData.org., https://ourworldindata.org/world-population-growth 2013. 
[2] Shaw R. P., Rapid Population Growth and Environmental Degradation: Ultimate versus Proximate Factors, Environ. Conserv., 16, 3, pp. 199 - 208,1989.

https://www.jstor.org/stable/44518343

[3] Beier G., Ullrich A., Niehoff S., Reißig M., Habich M.,Industry 4.0: How it is defined from a sociotechnical perspective and how much sustainability it includes - A literature review, J. Clean. Prod., 259, 120856, 2020.https://doi.org/10.1016/j.jclepro.2020.120856

[4] Müller J. M., Buliga, O.,Voigt, K. I.,Fortune favors the prepared: How SMEs approach business model innovations in Industry 4.0, Technol. Forecast. Soc. Change, 132, pp. 2-17, 2018.

https://doi.org/10.1016/j.techfore.2017.12.019

[5] Nara E. O. B., da Costa M. B., Baierle I. C., Schaefer J. L., Benitez G. B., do Santos L. M. A. L., BenitezL. B., Expected impact of industry 4.0 technologies on sustainable development: A study in the context of Brazil's plastic industry, Sustain. Prod. Consum., 25, pp.102-122, 2021.

https://doi.org/10.1016/j.spc.2020.07.018

[6] Hossain M.Z.,Water: The most precious resource of our life, GJAR, 2, 9, pp.1436 -1445, 2015.

[7] Wasewar K. L., Singh S., Sushil K., Chapter 13 - Process intensification of treatment of inorganic water pollutants in Inorganic Pollutants in Water, Elsevier, pp. 245- 271, 2020.

https://doi.org/10.1016/B978-0-12-818965-8.00013-5

[8] Kumbhar P., Savla N., Banerjee S., Mathuriya A.S., Sarkar A., Khilari S., Jadhav D. A., Pandit S., Chapter 26 - Microbial Electrochemical Heavy Metal Removal: Fundamental to the Recent Development in Wastewater Treatment, Elsevier, Shah M. P., Sarkar A., Mandal S., pp. 521- 542, 2021. https://doi.org/10.1016/B978-0-12-821881-5.00026-X

[9] Soares E.V., Soares H.M.V.M, Bioremediation of industrial effluents containing heavy metals using brewing cells of Saccharomyces cerevisiae as a green technology: A review, E.S.P.R., 19, 4, pp. 10661083, 2012. https://doi.org/10.1007/s11356-011-0671-5

[10] Gao X., Chen C.T. A., Heavy metal pollution status in surface sediments of the coastal Bohai Bay, Water Research, 46, 6, pp. 1901-1911, 2012. https://doi.org/10.1016/j.watres.2012.01.007

[11] Kobielska P. A., Howarth A. J., Farha O. K., Nayak S., Metal-organic frameworks for heavy metal removal from water, Coord. Chem. Rev, 358, pp. 92-107, 2018.

https://doi.org/10.1016/j.ccr.2017.12.010

[12] Zhang H., Zhang F., Song J., Tan M. L., Kung H. Johnson V.C., Pollutant source, ecological and human health risks assessment of heavy metals in soils from coal mining areas in Xinjiang, China, Environ. Res., 202, 111702, 2021. https://doi.org/10.1016/j.envres.2021.111702

[13] Fu F., Wang Q, Removal of heavy metal ions from wastewaters: A review, J. Environ. Manage., 92, 3, pp. 407- 418, 2011. https://doi.org/10.1016/j.jenvman.2010.11.011

[14] GRID-Arendal/Studio Atlantis, https://www.grida.no/resources/13718

[15] Lee M. E., Park J. H., Chung J. W., Lee C. Y. Kang S., Removal of Pb and $\mathrm{Cu}$ ions from aqueous solution by Mn3O4-coated activated carbon, J. Ind. Eng. Chem., 21, pp. 470- 475, 2015. https://doi.org/10.1016/i.jiec.2014.03.006

[16] Ján D., Branislav V., Introductory Chapter: Biosorption, in Biosorption, IntechOpen, 2018. https://doi.org/10.5772/intechopen.78961

[17] Fomina M., Gadd G. M., Biosorption: current perspectives on concept, definition and application, Bioresour. Technol., 160, pp. 3-14, 2014. https://doi.org/10.1016/j.biortech.2013.12.102

[18] Öztürk A., Artan T., Ayar A., Biosorption of nickel(II) and copper(II) ions from aqueous solution by Streptomyces coelicolor A3(2), Colloids Surf. B: Biointerfaces, 34, 2, pp.105-111,2004.

https://doi.org/10.1016/j.colsurfb.2003.11.008

[19] Chang J.S., Law R., Chang C. C., Biosorption of lead, copper and cadmium by biomass of Pseudomonas aeruginosa PU21, Water Research, 31, 7, pp. 1651- 1658, 1997.

https://doi.org/10.1016/S0043-1354(97)00008-0

[20] Matheickal J.T., Yu Q., Biosorption of lead(II) from aqueous solutions by Phellinus badius, Miner.

Eng., 10, 9, pp. 947- 957, 1997. https://doi.org/10.1016/S0892-6875(97)00076-9 
[21] Ojima Y., Kosako S., Kihara M., Miyoshi N., Igarashi K., Azuma M.,Recovering metals from aqueous solutions by biosorption onto phosphorylated dry baker's yeast, Sci. Rep., 9, 225, 2019. https://doi.org/10.1038/s41598-018-36306-2

[22] Kaewsarn P., Biosorption of copper(II) from aqueous solutions by pre-treated biomass of marine algae Padina sp., Chemosphere, 47, 10, pp.1081-1085, 2002. https://doi.org/10.1016/S00456535(01)00324-1

[23] Andrade A.D., Rollemberg M.C.E., Nóbrega J.A. Proton and metal binding capacity of the green freshwater alga Chaetophora elegans, Process Biochem., 40, 5, pp. 1931-1936, 2005.

https://doi.org/10.1016/j.procbio.2004.07.007

[24] Gupta V.K., Rastogi A., Saini V.K., Jain N., Biosorption of copper(II) from aqueous solutions by Spirogyra species, J. Colloid Interface Sci. , 296, 1, pp. 59-63, 2006.

https://doi.org/10.1016/j.jcis.2005.08.033

[25] Apiratikul R., Pavasant, P., Batch and column studies of biosorption of heavy metals by Caulerpa lentillifera, Bioresour.Technol., 99, 8, pp. 2766- 2777, 2008.

https://doi.org/10.1016/j.biortech.2007.06.036

[26]Prasanna K. Y., King P., Prasad V.S.R.K., Adsorption of zinc from aqueous solution using marine green algae-Ulva fasciata sp.Chem. Eng. Sci., 129, 1, pp. 161-166, 2007.

https://doi.org/10.1016/j.cej.2006.10.023

[27] El-Naggar N. E. A., Hamouda R. A., Mousa, I. E., Abdel-Hamid M. S., Rabei N. H., Biosorption optimization, characterization, immobilization and application of Gelidium amansii biomass for complete $\mathrm{Pb}^{2+}$ removal from aqueous solutions, Sci. Rep., 8, 13456, 2018. https://doi.org/10.1038/s41598-018$\underline{31660-7}$

[28] Bilal M., Rasheed T., Sosa-Hernández J.E., Raza A., Nabeel F., Iqbal H.M.N.. Biosorption: An Interplay between Marine Algae and Potentially Toxic Elements-A Review. Mar Drugs., 16, 65, 2018. https://doi.org/10.3390/md16020065

[29] Căpriță F. C., Ene A., Valorification directions for marine algae, Ann. Univ. Dunarea de Jos Galati Fasc. II Math. Phys. Mec. Theor., 42 (1), pp. 10-18, 2019. https://doi.org/10.35219/ann-ugal-math-physmec.2019.1.02

[30] Lähteenmäki-Uutela A., Rahikainen M., Camarena-Gómez M.T. Piparinen J., Spriling K., Yang B., European Union legislation on macroalgae products, Aquacult Int., 29, pp.487-509, 2021. https://doi.org/10.1007/s10499-020-00633-x

[31] https://fb.watch/7HzgFqNcQa/https://www.digi24.ro/galerie-foto/1/stiri/actualitate/plajeleau-fost-invadate-de-alge-apele-romane-au-strans-peste-10-000-de-tone-cele-mai-multe-dinsudul-litoralului-1643385\#6 (accessed on 29 August 2021)

[32] https://bit.ly/3BqxpKa https://spotmedia.ro/stiri/mediu/peste-3-000-de-tone-de-alge-au-foststranse-de-pe-litoral-in-prima-jumatate-a-lunii-august-topul-statiunilor-afectate (accessed on 29 August 2021)

[33] Directia Generala de Statistica Economica, Directia de Statistici Agricole si de Mediu, Anastasiu D., Institutul National de Statistica, Seria statistica mediului, Distributia apei si evacuarea aplor uzate in anul 2018

[34] Directia Generala de Statistica Economica, Directia de Statistici Agricole si de Mediu, Anastasiu D., Institutul National de Statistica, Seria statistica mediului, Distributia apei si evacuarea aplor uzate in anul 2019

[35] Population connected to wastewater treatment plants (env_ww_con) provided by Statistical Office of the European Uniion (Eurostat), https://www.eea.europa.eu/data-and-maps/indicators/urban-waste-watertreatment/urban-waste-water-treatment-assessment-5 (accessed online on 11 August 2021)

[36] Google Earth Version 9.144.0.2 - WebAssembly with threards, https://bit.ly/3gKIH4d (accessed online on 12 August 2021)

[37] Căpriță F. C., Ene A., Biosorption of heavy metals from the metallurgical industry wastewater by macroalgae, AIP Conference Proceedings,2218, 2019. https://doi.org/10.1063/5.0001087 